\title{
CONCURRENT LIABILITY IN CONTRACT AND TORT: RECOVERY OF PURE ECONOMIC LOSS AND THE EFFECT OF CONTRIBUTORY NEGLIGENCE
}

\author{
NICHOLAS RAFFERTY*
}

\section{INTRODUCTION}

Recently there has been a flurry of judicial activity concerning the possibility of concurrent liability in contract and tort for the negligent performance of a contract.' The decision of the Alberta Court of Appeal in Canadian Western Natural Gas Co. Ltd. v.Pathfinder Surveys $L t d{ }^{2}{ }^{2}$ constitutes an important addition to the jurisprudence on this topic because of the detailed consideration given to many of the issues arising in this context.

The facts are relatively straightforward. The plaintiff gas company engaged the defendant survey company to survey and stake the route for a proposed natural gas pipeline in northeast Calgary. The route included a gentle curve some 1000 feet in length. This curve necessitated the defendant staking two tangent lines and then measuring back from those lines to determine and stake the required curve. The defendant negligently failed to measure back from the tangent lines. As a result, the contractor excavated along the tangent lines and, realizing that the angle thus created would exceed that allowed in the relevant construction code, performed a field correction creating a curve sharper than planned but within construction code limits. The new line was outside the plaintiff's easement and conflicted with a proposed City of Calgary water line. The plaintiff was compelled to relocate that section of the line and sued the defendant for breach of contract for the cost of relocation.

The plaintiff was awarded damages at trial. The defendant appealed on a number of bases. The important ground, for present purposes, was the allegation that the plaintiff had been contributorily negligent in not noticing that the survey was defective.

Prowse J.A. (with whom Harradence J.A. concurred) delivered the majority opinion. He found that the plaintiff, through its employees, had been contributorily negligent and assessed its fault at 25 percent. The employees had observed the field corrections and should have realized that those corrections were made to deviate from, rather than to follow, the staked line, thus indicating that either the original plan or the survey had been defective. They should have appreciated that such an error was important in light of their knowledge that other utility lines were planned for the same area. The question, therefore, was whether such con-

* Of the Faculty of Law, University of Calgary.

1. This subject has also become increasingly popular with academics, see eg. Fridman, "The Interaction of Tort and Contract" (1977) 93 L.Q. Rev. 422; Considine, "Some Implications from Recent Cases on the Differences between Contract and Tort" (1978) 12 U.B.C.L. Rev. 85; Irvine, "Contract and Tort: Troubles Along the Border" (1980) 10 C.C.L.T. 281; Morgan, "The Negligent Contract Breaker" (1980) 58 Can. B. Rev. 299; Reiter, "Contracts, Torts, Relations and Reliance" in Reiter and Swan, Studies in Contract Law (1980) 235-311.

2. (1980) 12 Alta. L.R. (2d) 135 (C.A.). For a short but pithy comment on this case, see Irvine (1980) 12 C.C.L.T. 256. 
tributory negligence could be set up as a partial defence to an action for breach of contract.

Prowse J.A. determined that the first issue was whether the plaintiff could have framed its action in tort rather than in contract. This issue raised the general problem of when, if ever, there could be concurrent liability in contract and tort for the negligent performance of a contract and the specific problem of when purely economic loss could be recovered in an action in tort. On the assumption that the plaintiff could have sued in tort, the second issue was whether the plaintiff, by suing in contract, could avoid the effect of its contributory negligence and, in particular, section 1 of the Contributory Negligence Act. ${ }^{3}$

This comment focuses upon the judgment of Prowse J.A. and looks at the three problems identified in that judgment: concurrent liability in contract and tort, recovery of purely economic loss in tort and the defence of contributory negligence to an action for breach of contract. No attention is paid to the dissenting opinion of Haddad J.A. because his finding of no contributory negligence precluded any discussion of these three problems.

\section{CONCURRENT LIABILITY IN CONTRACT AND TORT}

In deciding whether the defendant could have been sued in tort, Prowse J.A. traced a line of recent English authority ${ }^{4}$ which recognized that the existence of a contractual relationship between the parties and a contractual duty of care did not preclude, but perhaps enhanced, the existence of a parallel duty of care in tort. These cases exploded the myth that concurrent liability in contract and tort was limited to people who carried on a "common calling". It can readily be inferred that Prowse J.A. wanted to follow this line of authority and to hold that the existence of a contract per se has no effect on potential tortious liability. He felt constrained, however, to deal with the limitation upon concurrent liability expressed by Pigeon J. when speaking for the majority of the Supreme Court of Canada in J. Nunes Diamonds Ltd. v. Dominion Electric Protection Co..5

Furthermore, the basis of tort liability considered in Hedley Byrme ${ }^{6}$ is inapplicable to any case where the relationship between the parties is governed by a contract, unless the negligence relied on can properly be considered as 'an independent tort' unconnected with the performance of that contract....

Whilst accepting the limitation imposed by Pigeon J., Prowse J.A. found that the defendant owed a duty of care to the plaintiff independent of contract. He said that such duty of care flowed from the Donoghue v. Stevenson "neighbour principle":

[T]he duty of care set out in Donoghue v. Stevenson . . . is not a contractual duty nor does it arise by virtue of there having been a contract between the parties or between one of the parties and

3. R.S.A. 1980 , c. C-23.

4. Esso Petroleum v. Mardon [1976] Q. B. 801 (C.A.); Batty v. Metropolitan Property Realisations [1978] Q.B. 554 (C.A.); Midland Bank Trust Co. v. Hett, Stubbs \& Kemp [1978] 3 All E.R. 571 (Ch. D.); Photo Production v. Securicor Transport [1978] 3 All E.R. 146 (C.A.). The Photo Production case was later reversed by the House of Lords on grounds unconnected with concurrent liability at [1980] 1 All E.R. 556 (H.L.).

5. (1972) 26 D.L.R. (3d) 699 at 727-728 (S.C.C.).

6. Hedley Byrne \& Co. Ltd. v. Heller \& Partners Ltd. [1964] A.C. 465 (H.L.).

7. [1932] A.C. 562 at $\mathbf{5 8 0}$ (H.L.).

8. Supra n. 2 at 151. 
another. The duty arises from proximity and neighbourhood. My neighbours are defined by Lord Atkin in Donoghue v. Stevenson as *... persons who are so closely and directly affected by my act that I ought reasonably to have them in contemplation as being so affected when I am directing my mind to the acts or omissions which are called in question', and he might have added, whether I am driving a car or performing a contract. This is a duty independent of contract and the neighbours referred to include 'those whom he intends to consume his products' whether they purchased the product from the manufacturer or others.

Prowse J.A. merely pays lip-service to the requirement of an independent tort. As one commentator has pointed out, "any "proximity' or 'neighbourhood' between the gas company and Pathfinder in this case came about entirely because of the contract between them, and in the course of its performance". ${ }^{9}$ Prowse J.A. may be saying that only in the case of potential Hedley Byrne liability need an independent tort be established. Pigeon J. himself, however, was clearly of the view that his dicta in Nunes Diamonds should not be so narrowly confined. In the later case of Smith v. McInnis, ${ }^{10}$ which dealt with the liability of a solicitor, he had no doubt that "a breach of duty may constitute a tort only if it is a breach of a duty owed independently of any contract with the claimant"."

It is unfortunate that Prowse J.A. did not seize the opportunity to subject Pigeon J.'s judgment in Nunes Diamonds to a more intense scrutiny. That decision should not be seen as a stumbling-block to a finding of concurrent liability in appropriate cases. In that case, the plaintiff diamond merchant contracted with the defendant for electronic burglary protection services for a small monthly charge. The contract provided that the defendant was not acting as an insurer of the protected property, that the charges were based solely on the value of the service and that liability was limited to the sum of $\$ 50$. It also provided that no conditions, warranties or representations had been made by the defendant other than those contained in the written agreement. After a burglary occurred at the premises of another diamond merchant protected by the same system supplied by the defendant, the plaintiff asked the defendant to send someone to inspect its system. An employee of the defendant made an inspection and said that "even our own engineers could not go through the system without setting an alarm". Copies of two letters written by the defendant's general manager to insurance brokers shortly after the burglary were also sent to the plaintiff's president. There were statements in those letters to the effect that an investigation was still continuing but that "the system performed its functions properly". No further information was forthcoming about the cause of the burglary. The plaintiff's premises were later burgled and a substantial quantity of diamonds were stolen by thieves who circumvented the alarm. The plaintiff brought an action against the defendant for breach of contract and in tort for negligent misstatement.

The contractual suit was dismissed by all judges at all levels because the plaintiff received the benefits for which he had bargained. There was no evidence that the equipment was defective in any way. The burglary was not attributable to any failure of performance in the system.

The main controversy centred around the action in tort. Despite a vigorous dissent by Spence J. (with whom Laskin C.J. concurred), Pigeon

9. Irvine, supra n. 2 at 259.

10. (1978) 91 D.L.R. (3d) 190 (S.C.C.).

11. Id. at 204. Pigeon $J$. was speaking from a position of dissent but not on this point on which the majority expressed no opinion. 
J., for the majority, may have been justified in rejecting Hedley Byrne liability in these circumstances. The reason Hedley Byrne liability may have been inappropriate, however, was not because the misrepresentations flowed from a contractual relationship between the parties. ${ }^{12}$ It was because the terms of the contract cannot be ignored in determining whether one of the parties should be liable under the Hedley Byrne principle. The contract in Nunes Diamonds provided that the defendant was not an insurer but was just in the business of supplying services. To have allowed the plaintiff to succeed may have effected a significant alteration of the contractual relationship between the parties. Pigeon J. himself recognized this point when he said: ${ }^{13}$

It is an essential basis of the contract between the parties that D.E.P. [the defendant] is not to be in the situation of an insurer. It is in consideration of this stipulation that the charges are established 'solely on the probable value of the service', not on the value of the goods intended to be protected. To make the protection company liable, in the case of the failure of its protection system, not for the stipulated nominal damages $(\$ 50)$ but for the full value of the goods to be protected, is a fundamental alteration of the contract.

Other judges have been able to place a narrow interpretation upon the Nunes Diamonds decision. Thus the British Columbia Court of Appeal in District of Surrey v. Carroll-Hatch and Associates ${ }^{14}$ had no difficulty in holding an architect concurrently liable in contract and tort and in distinguishing Nunes Diamonds on the following basis: ${ }^{15}$

In the Nunes case, the parties had by their contract agreed on the extent of the liability of the defendant in the event a breach of contract occurred. In those circumst ances, it was held that it was not appropriate to re-write the terms of the agreement between the parties to impose a greater liability than that agreed upon between the parties. However, it is clear that a party to a contract may, because of the relationship established thereby between the parties, assume common law duties in addition to the obligations imposed by the cont ract. When such a duty is not performed, it is not then open to the negligent party to attempt to avoid the consequences of his negligence by invoking the contract if its terms do not limit the liability.

A similar view is evident from the judgment of Weatherston J.A., dissenting, in the Ontario Court of Appeal decision of McGrath v. MacLean. ${ }^{16} \mathrm{He}$ said that in a tortious action between contracting parties the terms of the contract may be relevant in one of two ways. First, they may exclude or limit the liability of one of the parties for tortious performances of the contract. Second, even if there is no exclusion clause, they may "define the ambit of the risk assumed by contracting parties towards each other". ${ }^{17}$ Nunes Diamonds is an example of the latter effect.

One of the most influential decisions in the area of concurrent liability is the decision of the Ontario Court of Appeal in Dominion Chain Co. Ltd. v. Eastern Construction Co. $L t d .{ }^{18}$ In that case, the plaintiff contracted with

12. Indeed, in many cases the existence of a contract between the parties should serve to enhance the possibility of Hedley Byrne liability; see generally Symmons, "The Problem of the Applicability of Tort Liability to Negligent Misstatements in Contractual Situations: A Critique on the Nunes Diamonds and Sealand Cases"(1975) 21 McGill L.J. 79.

13. Supra n. 5 at 728. The problem with such an interpretation, however, is that the basis of the plaintiff's claim was rather that it had been "lulled into a false sense of security" by the defendant's misrepresentations than that the defendant was liable as an insurer of its system, see Ziegel, "Tortious Liability for Pre-contractual and Intracontractual Misrepresentations" (1976) 1 Can. Bus. L.J. 259 at 263-264.

14. [1979] 6 W.W.R. 289 (B.C.C.A.).

15. Id. at 311 .

16. (1979) 22 O.R. (2d) 784 (C.A.). The majority did not consider this aspect of the case.

17. Id. at 801 .

18. (1976) 68 D.L.R. (3d) 385 (Ont. C.A.); affd. sub nom. Giffels Associates Lid. v. Eastern Construction Co. Ltd. (1978) 84 D.L.R. (3d) 344 (S.C.C.). 
the first defendant, Eastern Construction, for the erection of a factory in accordance with designs provided by the second defendant, Giffels Associates, an engineering firm, which was also under contract to the plaintiff. The roof was poorly constructed with the result that leaks developed and equipment in the factory was damaged. Negligence was found on the part of both defendants.

One of the issues raised was whether both defendants could be classified as tortfeasors. Dealing first with the engineer, Jessup J.A., for the majority, had no doubt that it could be liable in tort for professional negligence in the performance of its contract. He relied upon Esso Petroleum v. Mardon ${ }^{19}$ as extending the duty of care owed by those in a common calling to those who "profess skills in a calling which a reasonable man would rely on". ${ }^{20}$ Whilst the contractor could not be said to profess skill in a calling, Jessup J.A. held that it could be liable in tort for negligent performance of a contract to build under the principle of Donoghue v. Stevenson. ${ }^{21}$ Nunes Diamonds was no barrier to a finding of concurrent liability against either defendant. That was simply a case where "the plaintiff could not escape contractual provisions 'with respect to the nature of the obligations assumed and the practical exclusion of responsibility for failure to perform them'22 by framing its action in tort". ${ }^{23}$

Wilson J.A., as she then was, issued a vigorous dissent on the scope of concurrent liability. She refused to extend the concurrent liability of professionals beyond the limited recognized categories in the absence of an "independent tort" within a broad reading of Pigeon J.'s judgment in Nunes Diamonds. She also thought that the presence of a contract severely restricted the scope of any potential Donoghue v. Stevenson liability: ${ }^{24}$

[I]t would appear that if the acts or omissions complained of by the plaintiff are in relation to the very matters covered by the contract the essence of the plaintiffs action is breach of the contractual duty of care rather than breach of the general duty of care owed to one's 'neighbour' in tort.

The majority decision in the Dominion Chain case has led to a widening of the classes of professionals subject to concurrent liability. Solicitors, in particular, have been found liable in tort as well as in contract. ${ }^{25}$ Very little difficulty is encountered in this context with the judgment of Pigeon $\mathrm{J}$.. The case is also important in showing that the existence of a contract per se should have no effect upon potential Donoghue v. Stevenson liability. It achieves this end by narrowing the dicta of Pigeon J. in the manner suggested and by indicating the true operation of the Nunes Diamonds decision. Prowse J.A., in the Pathfinder case, should have taken the same opportunity to deal directly with Pigeon J.'s judgment; instead, he decided to work within the framework of the "independent tort" test with the result that, nominally at least, Pigeon J.'s judgment stands unchallenged in Alberta.

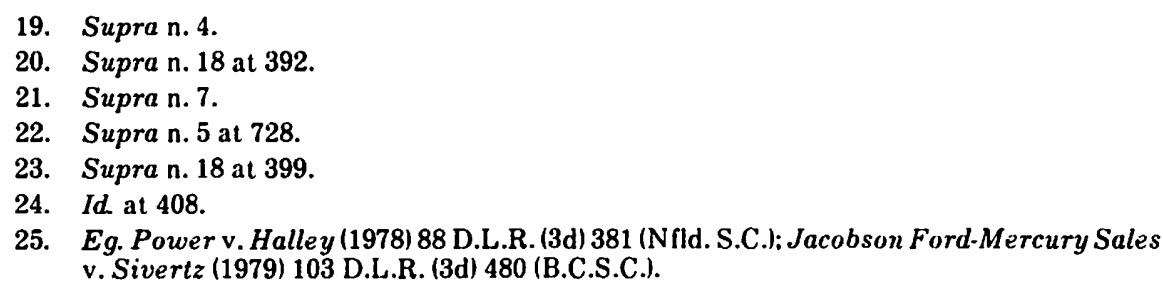
v. Sivertz (1979) 103 D.L.R. (3d) 480 (B.C.S.C.). 


\section{RECOVERY FOR PURE ECONOMIC LOSS}

A further stumbling-block to a finding of concurrent liability in Pathfinder was the purely economic nature of the loss suffered by the plaintiff. The majority of the Supreme Court of Canada in Rivtow Marine $L t d$. v. Washington Iron Works ${ }^{26}$ decided that a manufacturer of defective goods could not be liable under Donoghue v. Stevenson for the cost of repairing such goods or for loss of profits incurred whilst repairs were taking place. Such liability was contractual in origin and therefore could "not be enforced against the manufacturer by a stranger to the contract". 27

Prowse J.A. held that Rivtow Marine did not preclude the recovery of the economic loss in the present case but, rather, supported the plaintiff's position. He determined that the claim was not in respect of a defect in the product of the contract (the survey) but for the consequential loss of other property which the plaintiff suffered as a result of the defendant's negligence. The other property damaged was the rest of the pipeline which the plaintiff could not use unless the portion in question was moved back to its original alignment. He concluded that $R$ ivtow Marine would have allowed recovery for such consequential losses.

Whilst purporting to be an application of Rivtow Marine, Mr. Justice Prowse's judgment in fact constitutes an extension of that case. In Rivtow Marine, the majority of the Court accepted that there could be recovery against a manufacturer where the defective product caused personal injuries or damage to property, other than to the product in question, whether owned by the plaintiff or others. The damage to other property contemplated, however, was some physical property damage and there was no physical property damage to the pipeline. Arguably, on the basis of Rivtow Marine, any recovery for the costs of moving the pipeline should have sounded only in contract.

Rivtow Marine was similarly distinguished by the majority of the Ontario Court of Appeal in the Dominion Chain case ${ }^{28}$ when dealing with the liability of the builder. In that case, however, there was physical damage to property other than the factory, the product of the contract; namely, the factory equipment.

Mr. Justice Prowse's extension of Rivtow Marine was not, however, unwarranted. Any fears concerning indeterminate liability are met by the close proximity, created by the contractual relationship between the parties, between the negligence and the loss. The decision accords with what Megarry V.-C. said in the instructive case of Ross v. Caunters: ${ }^{29}$

There is clearly a high degree of proximity between the negligence and the loss. Plainly the defendants not only actually knew of the plaintiff individually (without any "or ought to have known'), but also knew that the negligence would be likely to cause her financial loss. Indeed, I find it difficult to envisage any test based on Donoghue v. Stevenson that would be stringent enough to exclude the plaintiff.

\section{THE EFFECT OF CONTRIBUTORY NEGLIGENCE}

Having concluded that the plaintiff could have framed its action in tort, Prowse J.A. had to decide whether the plaintiff, by suing in contract,

\footnotetext{
26. (1973) 40 D.L.R. (3d) 530 (S.C.C.).

27. Id. at 541.

28. Supra n. 18.

29. [1980] $1 \mathrm{Ch} .297$ at $320-321$.
} 
could avoid having its claim reduced because of the contributory negligence of its employees. In dealing with this issue, Prowse J.A. never considered the direct question of whether section 1 of the Contributory Negligence $\mathrm{Act}^{30}$ could apply to breaches of contract per se. Instead, he determined that an injustice would be done to the defendant if the plaintiff could avoid having its damages reduced by the simple device of framing its action in contract. He held, therefore, that, in the case of concurrent liability, a court can view the action as one in tort for the purpose of extending to the defendant the benefits of the apportionment legislation. A similar view has been taken in Saskatchewan in Husky Oil Operation $L t d$. v. Oster. ${ }^{31}$ Prowse J.A. thus avoids the difficult question of whether contributory negligence legislation can apply to contractual actions but he replaces it with the perhaps more difficult question of whether concurrent liability in contract and tort is available. ${ }^{32}$

The question of whether contributory negligence legislation can apply to contractual actions has plagued the courts for some years. There have been a few cases, in Canada ${ }^{33}$ and England, ${ }^{34}$ where such legislation has been applied to a breach of some contractual duty of care. Bugold J.A., dissenting, in Caines v. Bank of Nova Scotia, ${ }^{35}$ expressed this point very clearly when he said: ${ }^{36}$

I am inclined to hold that the Contributory Negligence Act $^{37} \ldots$ would apply 10 an action in contract ... which imposes a duty of care and there is a breach of a duty not to be negligent, or, as otherwise stated, a negligent breach of contract.

These cases have the support of Alberta's Institute of Law Research and Reform which has recommended that the defence of contributory negligence be available where there is a breach of a contractual duty of care. ${ }^{38}$ There are a number of cases, however, which have denied the applicability of the apportionment legislation to contractual actions. ${ }^{39} \mathrm{Given}$ the present state of the authorities, in the absence of statutory change,

30. Supra n. 3.

31. (1978) 87 D.L.R. (3d) 86 (Sask. Q.B.).

32. In Pathfinder and Husky Oil, the finding of concurrent liability and the consequent ap. plication of the apportionment legislation clearly benefitted the defendant. There have been cases where such a finding and application of the legislation have benefitted the plaintiff by repairing what would otherwise have been a break in the chain of causation, eg. Sole v. W.J. Hallt Ltd. [1973] Q.B. 574; dicta in Quinn v. Burch Bros. (Builders) Ltd. [1966] 2 Q.B. 370, affd. without considering this point, [1966]2 Q.B.381 (C.A.). For an excellent discussion of the whole area, see Palmer \& Davies, "Contributory Negligence and Breach of Contract - English and Australasian Attitudes Compared" (1980) 29 I.C.L.Q. 415.

33. E.g. Emil Anderson Construction Co. Ltd. v. Kaiser Coal Ltd., unreported, 1972, B.C.S.C., the relevant part of the judgment is set out by Klar, (1977) 3 C.C.L.T.206.208; West Coast Finance L td. v. Gunderson Stokes \& Co. (1974) 44 D.L.R. (3d) 232 (B.C.S.C.); revd. on other grounds, [1975] 4 W.W.R. 501 (B.C.C.A.); Truman v.Sparling Real Estate Ltd. (1977) 3 C.C.L.T. 205 (B.C.S.C.); the dissenting judgment of Bugold J.A. in Caines v. Bank of Nova Scotia (1978) 22 N.B.R. (2d) 631 (S.C. App. Div.).

34. Eg. the trial judgment in Quinn v. Burch Bros. (Builders) Ltd., supra n. 32; De Meza v. Apple [1974] 1 Lloyd's R. 508 (Q.B.D.); affd. without considering this point, [1975] 1 Lloyd's R. 498 (C.A.).

35. Supra n. 33.

36. R.S.N.B. 1973 , c. C-19.

37. Supra n. 33 at 653.

38. Report No. 31, Alberta Institute of Law Research and Reform, "Contributory Negligence and Concurrent Wrongdoers" (April 1979).

39. One of the more recent is Henuset Bros. L $\ell$ d. v. Pan Canadian Petroleum Ltd. (1977) 82 D.L.R. (3d) 345 (Alta. S.C.). 
the most satisfactory way to resolve the problem may lie in the concluding words of Prowse J.A. in Pathfinder: 40

One further comment I would make is that if I had concluded that the negligence set out above did not fall within s.2 of the Contributory Negligence Act, I would not have considered it beyond the scope of the common law to hold that when contributory negligence is set up as a shield against the obligation to satisfy the whole of a plaintifr's claim it should be given effect to on the principle that. where a man is part author of his own injury, he cannot call on the other party to compensate him in full. ... The fact that contributory negligence is often pleaded in answer to claims in contract, as it was here, and the fact that it is regularly applied by the business community in such circumstances, should be considered as support for the court extending the application of such principle to claims such as this. In doing so it would merely be applying generally a principle adopted in particular circumstances by the legislature in the Contributory Negligence Act.

There is some judicial support for this view in Pigeon J.'s judgment in Smith v. McInnis. ${ }^{41}$ On the assumption that contributory negligence legislation was not applicable to liability in contract, he believed that the same result could be achieved at common law. He was of the opinion that contributory negligence was never a complete defence in contract. He saw the basis of that doctrine as being that, if the plaintiff was himself negligent, he was in the position of a joint tortfeasor who would have no right of action against another tortfeasor. The rule precluding one tortfeasor from suing another never existed in contract. He therefore concluded that: ${ }^{42}$

The result is that the principle of causality must be applied and, therefore, there has to be an apportionment in the rare case of separate breaches of cont ract having contributed to a single loss.

\section{CONCLUSION}

Prowse J.A. trod warily through the complex issues raised in the Pathfinder case. In the result, his judgment has extended the law quite markedly and rationally in the areas identified in this comment. It would, however, have been a stronger judgment if it had grappled more directly with the issues. Prowse J.A. seems anxious to cloud his true thoughts by hiding behind the doctrine of precedent. Ultimately, one could make the same comment about this judgment as, in another context, Traynor C.J. did about one of his own judgments (Grant v. McA uliff $\left.{ }^{43}\right):^{44}$

It may not be amiss to add that alt hough the opinion in the case is my own. I do not regard it as ideally articulated, developed as it had to be against the brooding background of a pet rified forest. Yet I would make no more apology for it than that in reaching a rational result it was less deft than it might have been....

40. Supra n. 2 at 158-159.

41. Supra n. 10.

42. Id. at 207.

43. 41 Cal. 2d 859, 264 P. 2d 944 (1953).

44. Traynor, "Is This Conflict Really Necessary?" (1959) 37 Texas L. Rev. 657 at 670 n. 35. 